\title{
rs11940017 single nucleotide polymorphism of nuclear factor of kappa light polypeptide gene enhancer in B-cells 1 (NFKB1) gene is associated with post-renal transplant diabetes mellitus among Korean transplant recipients
}

\author{
Chan II Park, Yunmi Kim, Taehee Kim, Sun Woo Kang, Yeong Hoon Kim
}

Division of Nephrology, Department of Internal Medicine, Inje University Busan Paik Hospital, Busan, Korea

Background: The post-renal transplant diabetes mellitus (PTDM) results from insulin resistance after renal transplantation. Recent studies suggested that genetic polymorphisms of specific genes may be contributed to development of PTDM. The purpose of this study was to investigate the relationship with polymorphisms of nuclear factor of kappa light polypeptide gene enhancer in B-cells 1 and 2 (NFKB1 and NFKB2 gene) to the development of PTDM.

Methods: We selected the promoter polymorphisms (rs11940017 of NFKB1 gene, and rs12769316 of NFKB2 gene) and recruited the 256 non-PTDM subjects and 54 PTDM patients among Korean transplant recipients. Genotype of each single nucleotide polymorphism (SNP) was performed using direct sequencing. SNPstats and PASW ver. 18.0 program were used for genetic analysis.

Results: C allele distribution of rs11940017 in NFKB1 gene in the PTDM group (8.3\%) showed significantly higher compared to that of the non-PTDM group (3.7\%) (odds ratio [OR], 2.36; 95\% confidence interval [CI], 1.04-2.37; $\mathrm{P}=0.041$ ). The genotype distribution also associated with PTDM $(\mathrm{OR}, 2.99 ; 95 \% \mathrm{Cl}, 1.19-7.50 ; \mathrm{P}=0.02$ in codominant model [T/T vs. T/C]; OR, 2.64; $95 \% \mathrm{Cl}$, 1.08-6.49; $P=0.042$ in dominant model [T/T vs. T/C and C/C]). However, NFKB2 gene did not find any significant association with PTDM.

Conclusions: This study suggests that NKFB1 gene polymorphism may be contributed to development of PTDM in Korean population.

Corresponding author: Sun Woo Kang

E-mail: kswnephrology@gmail.com

(c) The Korean Society for Transplantation

This is an Open Access article distributed under the terms of the Creative Commons Attribution Non-Commercial License (http://creativecommons.org/licenses/by-nc/4.0/) which permits unrestricted non-commercial use, distribution, and reproduction in any medium, provided the original work is properly cited. 